\title{
Biomineralization of calcium carbonate by marine bacterial strains isolated from calcareous deposits
}

\author{
Julia Vincent ${ }^{1,2, *}$, René Sabot $^{2}$, Isabelle Lanneluc ${ }^{1}$, Philippe Refait ${ }^{2}$, Philippe Turcry ${ }^{2}$, Pierre-Yves Mahieux ${ }^{2}$, Marc \\ Jeannin $^{2}$, and Sophie Sablé ${ }^{1}$ \\ ${ }^{1}$ LIENSs UMR 7266 CNRS La Rochelle Université, avenue M. Crépeau, 17000 La Rochelle, France \\ ${ }^{2}$ LaSIE UMR 7356 CNRS La Rochelle Université, avenue M. Crépeau, 17000 La Rochelle, France
}

Received: 20 December 2019 / Accepted: 9 September 2020

\begin{abstract}
Biomineralization induced by microbial enzymes, which catalyse $\mathrm{CaCO}_{3}$ precipitation, is a promising field of research for various applications in building eco-materials. Especially, this could provide an eco-friendly process for protection of coastal areas against erosion. In the present investigation, fourteen bacterial strains were isolated and characterized from both natural seawater and calcareous deposits formed on a cathodically protected steel mesh in marine environment. All of them induced calcium carbonate precipitation in various media by producing urease and/or carbonic anhydrase enzymes. The calcium carbonate minerals produced by bacteria were identified by microscopy and $\mu$-Raman spectroscopy. In parallel, an experimental setup, based on a column reactor, was developed to study biomineralization and microbial capacity of Sporosarcina pasteurii to form sandy agglomerate. These well-known calcifying bacteria degraded the urea present in liquid medium circulating through the column to produce calcium carbonate, which acted as cement between sand particles. The bio-bricks obtained after 3 weeks had a compressive strength of $4.2 \mathrm{MPa}$. $20 \%$ of the inter-granular voids were filled by calcite and corresponded to $13 \%$ of the total mass. We successfully showed that bio-column system can be used to evaluate the bacterial ability to agglomerate a sandy matrix with $\mathrm{CaCO}_{3}$.
\end{abstract}

Keywords: biomineralization / calcareous deposits / marine bacteria / calcium carbonate precipitation / bio-bricks

Résumé. Biominéralisation du carbonate de calcium par des souches bactériennes marines isolées de dépôts calco-magnésiens. La biominéralisation induite par des enzymes microbiennes qui catalysent la précipitation du $\mathrm{CaCO}_{3}$ est un domaine de recherche prometteur pour diverses applications dans les écomatériaux de construction. Cela pourrait en particulier permettre d'établir un procédé écologique de protection des zones côtières contre l'érosion. Dans le cadre de la présente étude, quatorze souches bactériennes ont été isolées à partir d'eau de mer naturelle et de dépôts calcaires formés sur une grille en acier placée sous protection cathodique en milieu marin. Toutes ces bactéries ont induit la précipitation de carbonate de calcium dans divers milieux en produisant des enzymes uréase et/ou anhydrase carbonique. Les minéraux de carbonate de calcium produits par les bactéries ont été identifiés par microscopie et par spectroscopie $\mu$-Raman. En parallèle, un dispositif expérimental, basé sur un réacteur en colonne, a été développé pour étudier la biominéralisation et la capacité microbienne de Sporosarcina pasteurii à former un agglomérat sableux. Ces bactéries calcifiantes bien connues ont dégradé l'urée présente dans le milieu liquide circulant dans la colonne pour produire du carbonate de calcium qui a agi comme un ciment entre les particules de sable. Les bio-briques obtenues au bout de trois semaines avaient une résistance à la compression de 4,2 MPa. Vingt pour cent des vides intergranulaires ont été remplis de calcite et correspondent à $13 \%$ de la masse totale. Nous avons réussi à montrer que le système de biocolonne peut être utilisé pour évaluer la capacité des bactéries à agglomérer une matrice sableuse avec du $\mathrm{CaCO}_{3}$.

Mots clés : biominéralisation / dépôts calco-magnésiens / bactérie marine / précipitation du carbonate de calcium / bio-briques

\footnotetext{
* e-mail: julia.vincent1@univ-lr.fr
} 


\section{Introduction}

Coastal erosion poses a severe threat as it causes degradation of dunes, beaches, cliffs and breakdown of dikes. Coastal erosion is recognized as the permanent loss of land along the shoreline resulting in the transformation of the coast. Over the last 50 years, nearly $20 \%$ of the French natural coastline has receded and about $30 \mathrm{~km}^{2}$ of land have disappeared [1]. In order to protect coastal areas and structures, it is necessary to find an effective means of fighting erosion with a low impact on the environment. The possibility way to promote the formation of an eco-material by electrochemistry has been envisioned as a means to stabilize the profile of beaches and to improve the anchoring of rocks used as breakwaters [2]. The process uses cathodic polarization of a metal structure that promotes the formation of a calcareous layer, composed of calcium carbonate $\left(\mathrm{CaCO}_{3}\right)$ and magnesium hydroxide $\left(\mathrm{Mg}(\mathrm{OH})_{2}\right)$, close to the metal. These calcareous deposits act as a cement between sediments, shells, and pebbles, and give rise to a solid agglomerate that could reinforce dikes and delay the erosion of beaches. As this process evolves in a natural marine environment, the presence of numerous microorganisms could also influence the formation of calcareous deposits and it is necessary to take this into account. Indeed, some microorganisms are able to promote a mineral precipitation, called biomineralization. A local microenvironment is generated by microorganisms, which provides optimal conditions for the mineral precipitation [3]. In marine environment, this phenomenon is responsible, in the long term, for the formation of rocks such as stromatolites [4] or beachrocks $[5,6]$. Calcium carbonate is one of the most abundant minerals on earth, comprising $4 \%$ in weight of the earth's crusts [7]. Several microbial metabolic processes are able to induce the precipitation of calcium carbonate minerals (biocalcification) both in marine and terrestrial environments: urea hydrolysis, ammonification of amino acids, denitrification, dissimilatory sulphate reduction and photosynthesis [7-9]. The most widely studied metabolic pathway is urea hydrolysis driven by bacterial urease, which leads to an alkalization of the medium inducing precipitation of $\mathrm{CaCO}_{3}[8,10-12]$. This metabolism could be applied in particular to the repair of concrete building materials [13], the stabilization of soils [14], the depollution of materials contaminated with heavy metals [15] and the consolidation of sandy substrate $[16,17]$. Carbonic anhydrase enzymes are also involved in the formation of $\mathrm{CaCO}_{3}$ precipitates under natural conditions and can act synergistically with urease $[18,19]$. Carbonic anhydrase promotes the interconversion of $\mathrm{CO}_{2}$ into $\mathrm{HCO}_{3}{ }^{-}$and $\mathrm{H}^{+}$, which under certain conditions can capture atmospheric $\mathrm{CO}_{2}$ [20,21]. In the context of coastal protection, our purpose is to design ecomaterials that mimic naturally-formed rock structures at the seaside and to accelerate their growth kinetics by coupling electrochemical processes with microbial mechanisms of biomineralization. To do this, it is necessary in a first step to identify marine bacteria able to induce biomineralization and more specifically biocalcification. In this work, fourteen marine bacteria have been isolated from both natural seawater and calcareous deposits formed on a cathodically protected steel mesh in marine environment. The mineralization products and metabolic pathway involved in biocalcification have been characterized. Simultaneously, an experimental set-up of bio-solid column has been developed and validated by using a well-known calcifying bacterium, Sporosarcina pasteurii DSM33, able to agglomerate a sandy substrate. The calcareous-sand agglomerate obtained has been mechanically tested.

\section{Materials and methods}

In order to explicit the various types of experiments and the links between them, the experimental procedure is summarized in Figure 1.

\subsection{Culture media and solutions}

Two different media were used to isolate and cultivate marine bacteria:

- the first one, Marine Broth (MB) (Condalab), was composed of ammonium nitrate $0.0016 \mathrm{~g} / \mathrm{L}$, bacteriological peptone $5 \mathrm{~g} / \mathrm{L}$, boric acid $0.022 \mathrm{~g} / \mathrm{L}$, anhydrous calcium chloride $1.8 \mathrm{~g} / \mathrm{L}$, disodium phosphate $0.008 \mathrm{~g} / \mathrm{L}$, anhydrous magnesium chloride $8.8 \mathrm{~g} / \mathrm{L}$, potassium bromide $0.08 \mathrm{~g} / \mathrm{L}$, potassium chloride $0.55 \mathrm{~g} / \mathrm{L}$, sodium bicarbonate $0.16 \mathrm{~g} / \mathrm{L}$, sodium chloride $19.4 \mathrm{~g} / \mathrm{L}$, sodium fluoride $0.0024 \mathrm{~g} / \mathrm{L}$, sodium silicate $0.004 \mathrm{~g} / \mathrm{L}$, sodium sulphate $3.24 \mathrm{~g} / \mathrm{L}$, strontium chloride $0.034 \mathrm{~g} / \mathrm{L}$, yeast extract $1 \mathrm{~g} / \mathrm{L}$, ferric citrate $0.1 \mathrm{~g} / \mathrm{L}$. From this one, two media were produced: MB enriched with calcium chloride dihydrate at the concentration of $3.7 \mathrm{~g} / \mathrm{L}$ (named $\mathrm{MB}+\mathrm{CaCl}_{2}$ ) and $\mathrm{MB}$ enriched with calcium chloride dihydrate at the concentration of $3.7 \mathrm{~g} / \mathrm{L}$ and urea at the concentration of $20 \mathrm{~g} / \mathrm{L}$ (named $\mathrm{MB}+\mathrm{CaCl}_{2}+$ urea);

- the second medium, M1, was adapted from the study of Silva-Castro et al. [22]. Its composition was yeast extract $10 \mathrm{~g} / \mathrm{L}$, peptone $5 \mathrm{~g} / \mathrm{L}$, glucose $1 \mathrm{~g} / \mathrm{L}$ and sea salts (Sigma) $30 \mathrm{~g} / \mathrm{L}$. From this one, two media were produced: M1 enriched with calcium chloride dihydrate at the concentration of $3.7 \mathrm{~g} / \mathrm{L}$ (named $\mathrm{M} 1+\mathrm{CaCl}_{2}$ ) and M1 enriched with calcium chloride dihydrate at the concentration of $3.7 \mathrm{~g} / \mathrm{L}$ and urea at the concentration of $20 \mathrm{~g} / \mathrm{L}$ (named $\mathrm{M} 1+\mathrm{CaCl}_{2}+$ urea).

The media used to cultivate non-marine bacteria for the control experiments and the bio-solid column were:

- medium 220 (M220) composed of peptone from casein $20 \mathrm{~g} / \mathrm{L}$, sodium chloride $5 \mathrm{~g} / \mathrm{L}$, with urea at the concentration of $20 \mathrm{~g} / \mathrm{L}$;

- tryptic Soy Broth (TSB) composed of tryptone $17 \mathrm{~g} / \mathrm{l}$, papaic digest of soybean meal $3 \mathrm{~g} / \mathrm{L}$, glucose $2.5 \mathrm{~g} / \mathrm{L}$, dipotassium phosphate $2.5 \mathrm{~g} / \mathrm{L}$, sodium chloride $5 \mathrm{~g} / \mathrm{L}$, $\mathrm{pH}$ of the ready use medium $\left(25^{\circ} \mathrm{C}\right) 7.3 \pm 0.2$.

All these media were solidified by adding agar $12 \mathrm{~g} / \mathrm{L}$.

Artificial seawater (ASW) based on the standard ASTM D1141 (Standard specification for substitute ocean water, corrosion testing procedures, 1992) was prepared for isolation of marine bacteria. It was composed of sodium 

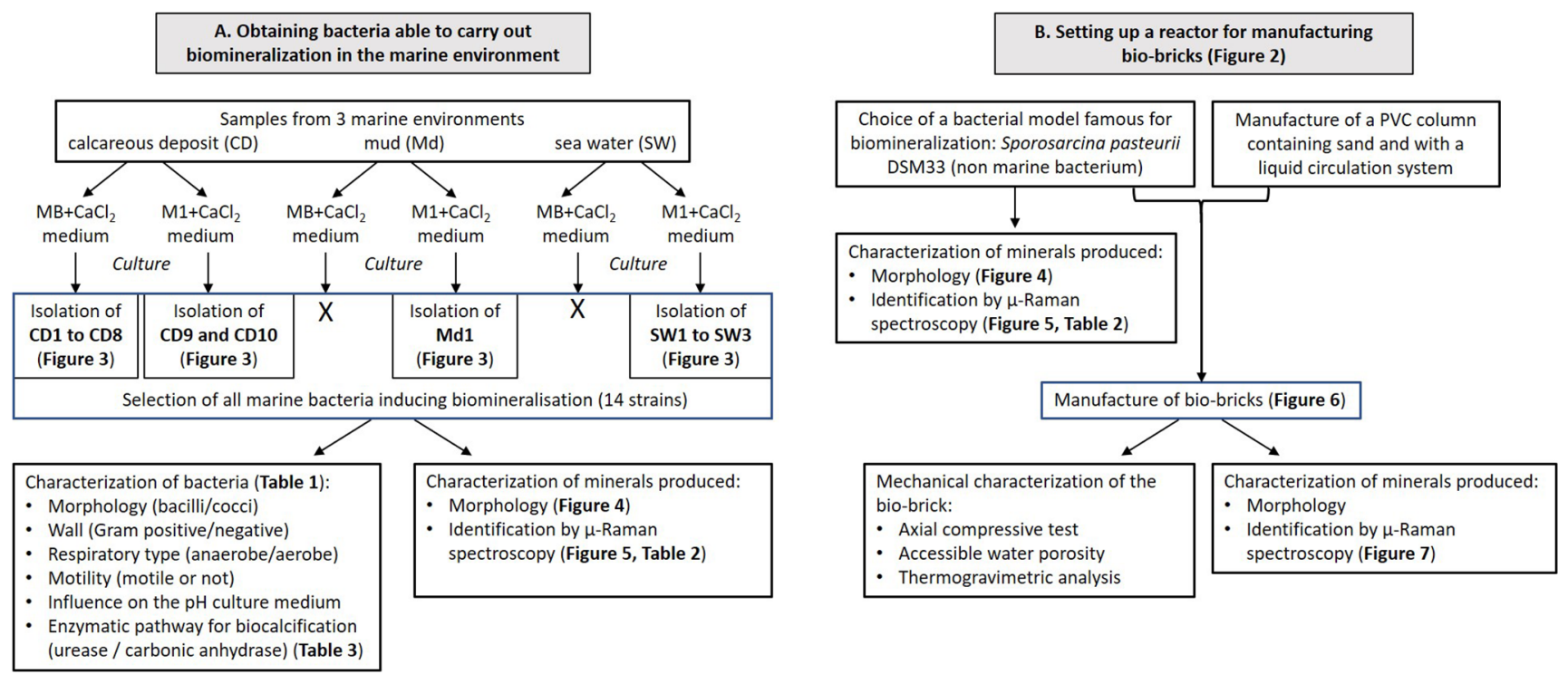

Fig. 1. Experimental procedure for obtaining bacteria able to carry out biomineralization in the marine environment (A) and setting up a reactor for manufacturing bio-bricks (B). X: no colonies with mineral precipitation on their surface.

chloride $24.54 \mathrm{~g} / \mathrm{L}$, calcium chloride dihydrate $1.54 \mathrm{~g} / \mathrm{L}$, magnesium chloride hexahydrate $11.1 \mathrm{~g} / \mathrm{L}$, sodium sulphate $4.09 \mathrm{~g} / \mathrm{L}$, potassium chloride $0.69 \mathrm{~g} / \mathrm{L}$ and sodium carbonate $0.23 \mathrm{~g} / \mathrm{L}$.

Cementation medium, used for the bio-solid column, was composed of Nutrient Broth (NB) $0.5 \mathrm{~g} / \mathrm{L}$, enriched with calcium chloride dihydrate at the concentration of $3.7 \mathrm{~g} / \mathrm{L}$ and urea at the concentration of $20 \mathrm{~g} / \mathrm{L}$, at the $\mathrm{pH}$ of 7.5 .

\subsection{Sampling, bacterial strains and culture conditions}

To isolate marine bacteria inducing biomineralization, samples were collected from two different sites. Natural seawater and calcareous deposits developed by cathodic polarization on steel grid during 6 months were sampled in La Rochelle harbour (Atlantic coast, France). Natural seawater and mud were also sampled on the Atlantic coast in Angoulins (village close to La Rochelle, France).

Approximately $4 \mathrm{~g}$ of calcareous deposits were placed in $50 \mathrm{~mL}$ of $\mathrm{MB}+\mathrm{CaCl}_{2}, \mathrm{MB}+\mathrm{CaCl}_{2}+$ urea, $\mathrm{M} 1+\mathrm{CaCl}_{2}$, $\mathrm{M} 1+\mathrm{CaCl}_{2}+$ urea and incubated at $25^{\circ} \mathrm{C}$, with shaking of $130 \mathrm{rpm}$, for 1 week. For each culture condition, bacteria were isolated by the serial dilution method consisting of plating the samples on solid media $\mathrm{MB}+\mathrm{CaCl}_{2}, \mathrm{MB}+$ $\mathrm{CaCl}_{2}+$ urea, $\mathrm{M} 1+\mathrm{CaCl}_{2}, \mathrm{M} 1+\mathrm{CaCl}_{2}+$ urea, and incubated for 3 days at $25^{\circ} \mathrm{C}$.

Bacterial strains contained in natural seawater of both sites and in mud from Angoulins were isolated by the serial dilution method in ASW solution by plating the samples on solid medium $\mathrm{M} 1+\mathrm{CaCl}_{2}$ for 3 days at $25^{\circ} \mathrm{C}$.

Bacterial strains with mineral precipitation on the surface of colonies were isolated and characterized. Strains were conserved as frozen stocks with $25 \%$ glycerol at $-80^{\circ} \mathrm{C}$. For all tests, the bacteria were grown at $30^{\circ} \mathrm{C}$ in their respective isolation medium.
Sporosarcina pasteurii DSM33, used for the biocalcification assays in bio-solid column, was cultivated in M220 medium $+2 \%$ urea at $30^{\circ} \mathrm{C}$. Escherichia coli ATCC 25922 and Proteus mirabilis ATCC 25933, used as controls for urease activity assay, were cultivated in TSB medium at $37^{\circ} \mathrm{C}$, corresponding to optimal growth temperature.

\subsection{Morphological characterization of isolated bacterial strains}

Morphological characterization of colonies and cells was performed by standard methods.

Bacterial colonies were observed with binocular magnifying glass Leica M165C (x1.25 to x12).

Gram stain for light microscopy was done on heat-fixed smears of bacteria according to the following procedure. The bacteria were flooded with a dye (crystal violet) for 60 seconds, then flooded with a mordant (lugol solution) for an additional 60 seconds to fix the staining, and gently washed under running tap water. Bacteria were decolorized with ethanol $95^{\circ}$, washed with water and counterstained with fuchsin for 60 seconds. Cells were then washed with water, blotted dry, and observed by light microscopy (Leica microscope LEITZ Biomed, x1000).

For the motility experiment, bacterial suspensions were prepared with the MB medium inoculated with bacteria, incubated at $30^{\circ} \mathrm{C}$ with shaking of $130 \mathrm{rpm}$ for 24 hours. A droplet was placed between a lamella and a glass slide. The motility was observed with Leica microscope LEITZ Biomed (x1000).

\subsection{Respiratory type of isolated bacterial strains}

Each isolated strain was inoculated on the surface of respective solid medium in aerobic and anaerobic conditions and was incubated at $25{ }^{\circ} \mathrm{C}$ for 3 days. The 


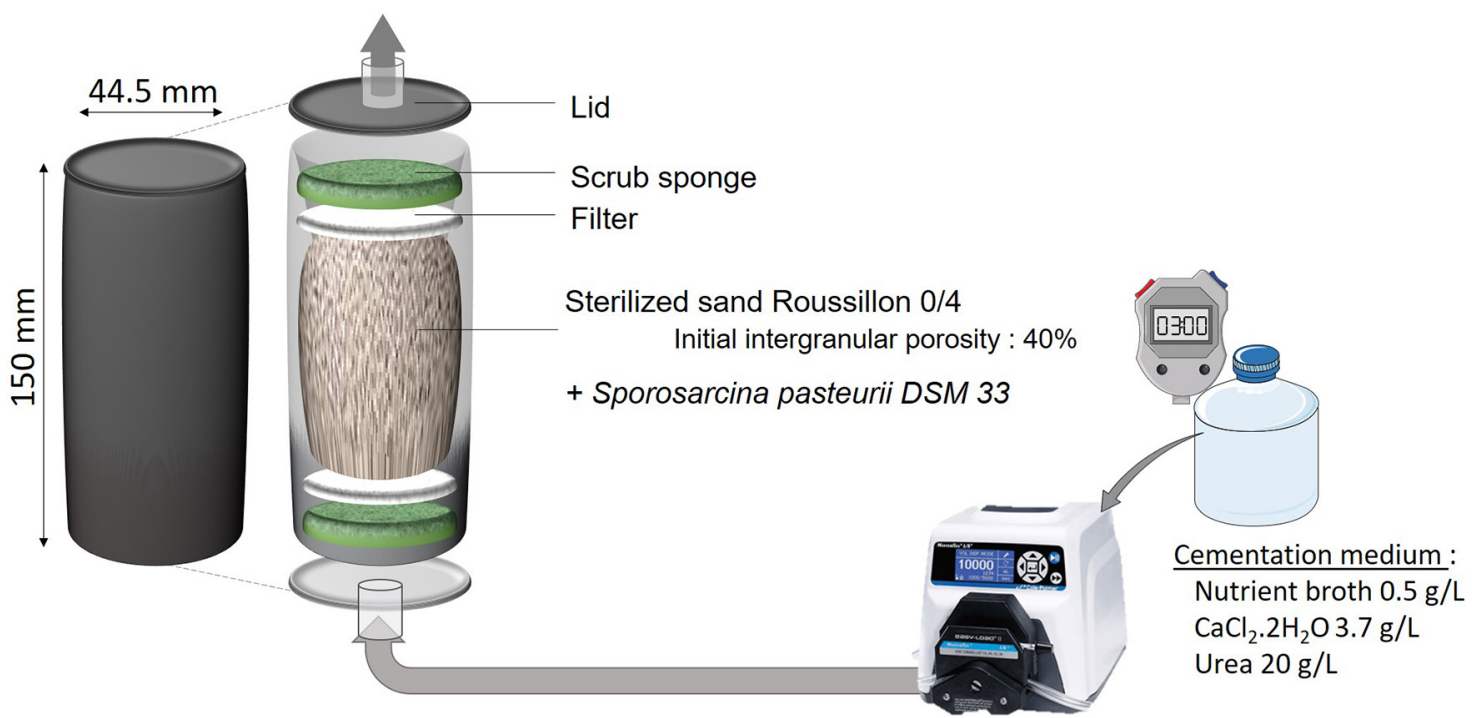

Fig. 2. Set-up of the column reactor adapted from Henze and Randall [23].

anaerobic conditions were realised by using $\mathrm{GasPak}^{\mathrm{TM}} \mathrm{EZ}$ Anaerobe container system (Becton, Dickinson and company) in airtight container.

\subsection{Determination of medium $\mathrm{pH}$}

pH of samples was measured with a WTW pH-meter 3310 with electrode SENTIX Mic-D (WTW).

\subsection{Urease activity assay}

Indole urea solution (Biomérieux) was used to determine bacterial urease activity. It is composed of L-tryptophan $3 \mathrm{~g} / \mathrm{L}$, potassium dihydrogen phosphate $1 \mathrm{~g} / \mathrm{L}$, dipotassium hydrogen phosphate $1 \mathrm{~g} / \mathrm{L}$, sodium chloride $5 \mathrm{~g} / \mathrm{L}$, urea $20 \mathrm{~g} / \mathrm{L}$, phenol red $0.025 \mathrm{~g} / \mathrm{L}$, alcohol $95^{\circ} 0.01 \mathrm{ml} / \mathrm{L}$ and final $\mathrm{pH}$ (at $25^{\circ} \mathrm{C}$ ) $6.8 \pm 0.2$. Several colonies of each isolated bacterium were inoculated in $1 \mathrm{~mL}$ of indole urea medium. Samples were placed at $30^{\circ} \mathrm{C}$ for 24 hours. The ability of the bacterial isolates that produce urease leads to $\mathrm{NH}_{4}^{+}$release and then increases the $\mathrm{pH}$ into alkaline domain. As a result, the colour of the medium turns pink. Escherichia coli ATCC 25922 was used as negative control of urease activity and Sporosarcina pasteurii DSM 33 and Proteus mirabilis ATCC 25933 were used as positive controls of urease activity.

\subsection{Carbonic anhydrase activity assay}

The assay of carbonic anhydrase (CA) activity was carried out with para nitrophenol acetate (p-NPA), which is a colour indicator. A solution of $20 \mathrm{mM}$ phosphate buffer and $1 \mathrm{~mol} / \mathrm{L} \mathrm{p}-\mathrm{NPA}$ was used for this assay. Bacterial colonies, grown on solid medium for 24 hours, were put in $3 \mathrm{ml}$ of reaction solution and then incubated at ambient temperature for 1 hour. The esterase activity of CA was measured by colour change of the solution induced by hydrolysis of $\mathrm{p}-$ NPA used as CA substrate. Negative control was done with
$3 \mathrm{~mL}$ of reaction solution and sterile culture medium without bacteria. Escherichia coli ATCC 25922 was used as positive control of CA activity.

\subsection{Crystals morphology}

Isolated bacterial strains grew on respective solid isolation media enriched in calcium (MB $+\mathrm{CaCl}_{2}$ or $\mathrm{M} 1+\mathrm{CaCl}_{2}$ ) for 3 days at $25^{\circ} \mathrm{C}$. Morphology of mineralization products at the surface of the colonies was observed with binocular magnifying glass Leica M165C (x1.25 to x12).

\subsection{Crystals identification by $\mu$-Raman spectroscopy}

$\mu$-Raman spectroscopy analysis was performed at room temperature on a Jobin Yvon High Resolution Raman Spectrometer (LabRAM HR Evo) equipped with a microscope (Olympus BX 41), a Peltier-based cooled charge coupled detector (CCD) and a Near Infra-Red diode laser $(785 \mathrm{~nm})$. The acquisition time was variable and depended on fluorescence background of the spectrum due to the organic matter. It was generally equal to 60 seconds but could be increased up to 5 minutes to optimize the signal to noise ratio. At least 5 or 6 zones (diameter of approximately $2 \mu \mathrm{m}$ ) of a given deposit were analysed through a Long Working Distance $50 \times$ objective, with a resolution estimated at $0.1 \mathrm{~cm}$.

\subsection{Experimental set-up of bio-solid column}

An experimental set-up based on a column reactor was built to study biomineralization and microbial capacity to consolidate sand. The scheme is shown in Figure 2. This experimental set-up has been adapted from experimentations of Henze and Randall [23]. The column had an inside diameter of $44.5 \mathrm{~mm}$ and a length of $150 \mathrm{~mm}$. The bottom and top lids were identical and removable, both sealed with an O-ring. Additionally, a scrub sponge and a filter were 
cut into a cylindrical shape with a diameter of $44 \mathrm{~mm}$ and placed on both sides of the column. A $0 / 4 \mathrm{~mm}$ pure $\mathrm{SiO}_{2}$ sand (from Kleber Moreau Roussillon aggregates quarry), which is similar to that of masonry sand, was used for these experiments. It was sterilised at $115^{\circ} \mathrm{C}$ for $20 \mathrm{~min}$.

Bacterial culture was prepared with Sporosarcina pasteurii DSM33 in $100 \mathrm{ml}$ of M220 medium $+2 \%$ urea and incubated for 24 hours. For the inoculation of the sand with bacteria, $350 \mathrm{~g}$ of sand was mixed with this bacterial culture and shaked slowly $(60 \mathrm{rpm})$ for 4 hours at $30^{\circ} \mathrm{C}$, to favour bacterial adhesion to the sand. The sand-bacteria mixture was then added to the column. The remaining liquid was drained through the outlet. The column was then closed and bacteria were kept for 3 hours. The system was connected through a peristaltic pump to a bottle containing sterile cementation medium. $50 \mathrm{~mL}$ of cementation medium was injected every 3 hours at a rate of $10 \mathrm{ml} /$ min during 3 weeks from the bottom of the column. The liquid that flowed out on the top of the column was collected in order to check the $\mathrm{pH}$.

\subsection{Mechanical and physical analyses of the cemented sandy column}

Axial compressive test and accessible water porosity were performed on a cylindrical calcareous agglomerate of $43.2 \mathrm{~mm}$ in diameter and $50.2 \mathrm{~mm}$ in height that have been sawn with a circular saw from the top of the column. The difference between the agglomerate diameter and the internal diameter of the column was due to the column drying (one week at $37^{\circ} \mathrm{C}$ ). The axial compressive test consisted of increasing the load progressively at the rate $50 \mathrm{~N} / \mathrm{s}$ until the fracture (one replicate). The compressive strength in megapascals ( $\mathrm{MPa}$ ) is considered as the ratio between the maximum load at fracture $(\mathrm{Fc})$ and the area where the load is applied (Ac). The accessible water porosity was measured according to the AFPC-AFREM procedure and assessed from water saturation under vacuum (AFPC-AFREM 1997). Specimens were watersaturated during $24 \mathrm{~h}$ under vacuum (around $2.5 \mathrm{kPa}$ ) and then oven-dried at $105^{\circ} \mathrm{C}$. Volumes were determined by hydrostatic weighing. The water porosity is then defined as the intergranular voids volume on total volume ratio and was averaged with 8 replicates. The initial intergranular porosity, said to be accessible to water, corresponds to the initial void volume and is expressed as a function of the total volume of the sample:

$$
\begin{aligned}
& \text { Initial intergranular porosity } \% \\
& \qquad=\frac{\text { Volume of voids }\left(\mathrm{cm}^{3}\right)}{\text { Volume of the column }\left(\mathrm{cm}^{3}\right)} \times 100,
\end{aligned}
$$

where

$$
\begin{aligned}
& \text { Volume of voids }\left(\mathrm{cm}^{3}\right)=\text { volume of the column }\left(\mathrm{cm}^{3}\right) \\
& \qquad-\frac{\text { Mass of the sand }(\mathrm{g})}{\text { Density of the sand }\left(2.65 \mathrm{~g} / \mathrm{cm}^{3}\right)} .
\end{aligned}
$$

Thermogravimetric analysis (TGA) was performed on a Setaram Setsys Evolution 16/18 apparatus. $241.2 \mathrm{mg}$ of samples were heated from $20^{\circ} \mathrm{C}$ to $1000^{\circ} \mathrm{C}$ at a $10^{\circ} \mathrm{C} / \mathrm{min}$ heating rate, under neutral argon atmosphere. To get more accurate results, data were analysed through the differential thermogravimetric curves. TGA results provide the $\mathrm{CaCO}_{3}$ content of the tested sample.

\section{Results and discussion}

\subsection{Isolation and characterization of marine bacteria inducing biomineralization}

Calcareous deposits, seawater and mud samples were taken in order to isolate bacterial strains able to induce biomineralization. After 1 week in two culture media $\left(\mathrm{MB}+\mathrm{CaCl}_{2}\right.$ and $\left.\mathrm{M} 1+\mathrm{CaCl}_{2}\right)$, bacteria were deposited on the respective agar media (Fig. 1). After growth for 3 days, among all the bacteria that developed, only 14 colonies presented mineral precipitation on their surface. These bacteria were then isolated on the respective agar media (see bacterial colonies in Fig. 3). Isolated strains were denoted CDi ( $i=1$ to 10 ) for bacteria taken from the calcareous deposit (CD), Md1 for bacteria coming from the mud in Angoulins coast, and SWi ( $i=1$ to 3 ) for bacteria from seawater sampled in La Rochelle harbour or Angoulins coast (Fig. 1).

The 14 marine strains have been characterized according to their morphotype by Gram coloration, their respiratory type, their motility and the $\mathrm{pH}$ of their culture medium (Tab. 1). We mostly observed motile bacilli types with a majority of Gram-negative bacteria (71\%). This result is consistent with the predominance of Proteobacteria among the bacterial communities in seawater [24,25]. In our work, twelve of the isolated bacteria were facultative anaerobe (FA) and two were obligate aerobe (OA). The pH of the liquid culture medium $\mathrm{MB}+\mathrm{CaCl}_{2}$ or $\mathrm{M} 1+\mathrm{CaCl}_{2}$ (according to the strains, see Tab. 1), initially at $7.5 \pm 0.1$, increased to $7.9 \pm 0.1$ for CD6, CD9, CD10, SW3 and up to $8.2 \pm 0.2$ for $\mathrm{CD} 8$, after 3 days of incubation at $25^{\circ} \mathrm{C}$. All isolated strains alkalinized their culture medium. Indeed, the bacteria responsible for the phenomenon of biocalcification are known to induce alkalization of their environment to favour the mineral precipitation $[7,8]$.

By their metabolism, these isolated strains were responsible for cell environment alkalinisation, allowing them to precipitate mineral agglomerates on the surface of their colonies during their growth on solid medium.

\subsection{Identification of $\mathrm{CaCO}_{3}$-precipitating bacteria and characterization of the precipitated crystals in solid and liquid media}

Optical microscopy and $\mu$-Raman spectroscopy were used to characterize the minerals produced by the 14 marine bacterial strains studied and by the biocalcifying bacterium model, Sporosarcina pasteurii DSM 33, grown in several solid and liquid culture media: $\mathrm{MB}+\mathrm{CaCl}_{2}, \mathrm{MB}+\mathrm{CaCl}_{2}+$ urea, $\mathrm{M} 1+\mathrm{CaCl}_{2}, \mathrm{M} 1+\mathrm{CaCl}_{2}+$ urea. All bacterial strains produced a high number of crystals on solid agar after 3 

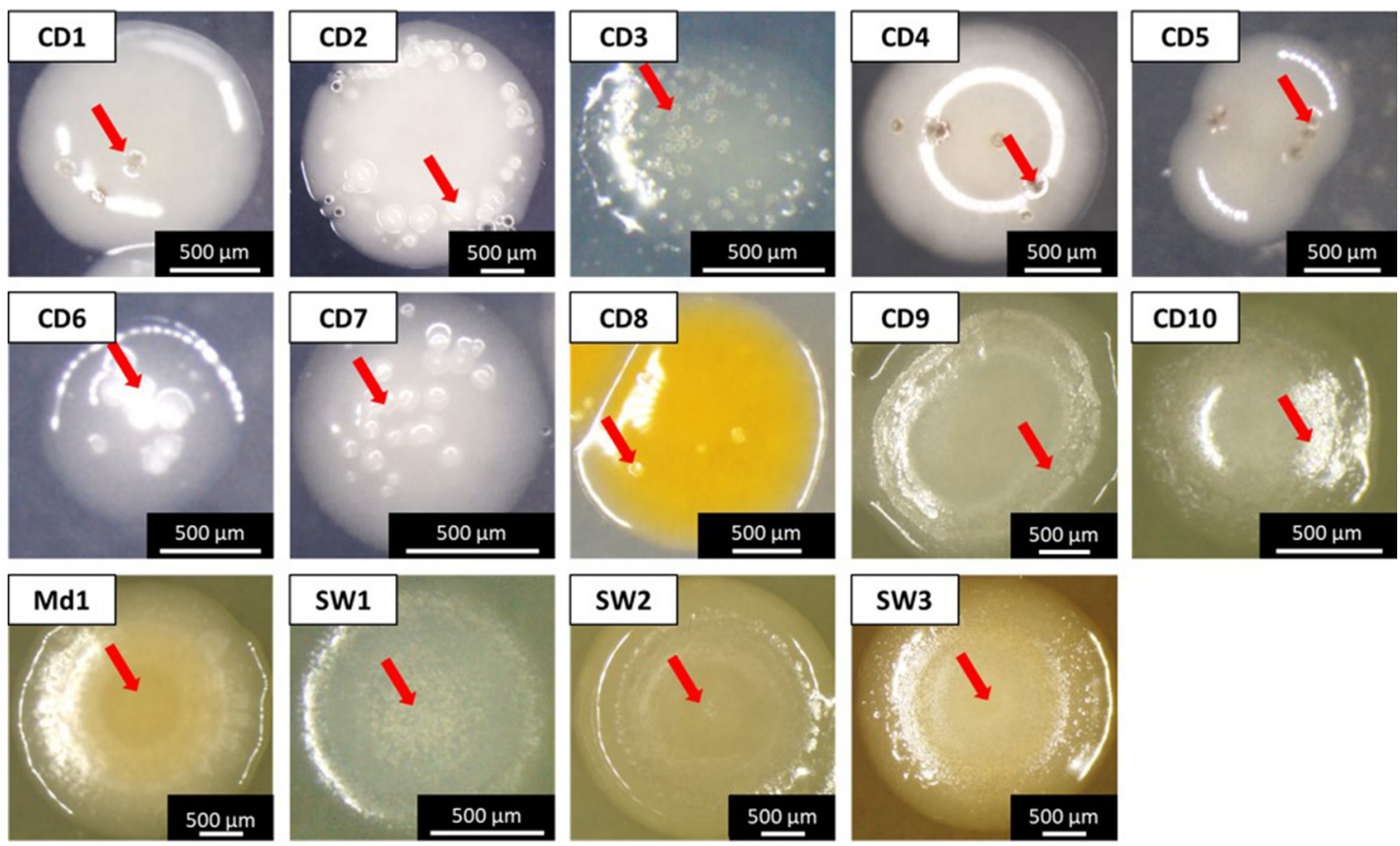

Fig. 3. Colonies of marine bacterial strains with mineral crust on the surface of the colonies. CD1 to CD 8 were isolated on solid $\mathrm{MB}+\mathrm{CaCl}_{2}$, other bacteria were isolated on solid $\mathrm{M} 1+\mathrm{CaCl}_{2}$ for 3 days at $25^{\circ} \mathrm{C}$. Arrows indicate mineral agglomerate induced by bacteria.

days whereas no crystals were found in control plates inoculated without bacteria. Figure 4 shows crystals formed on the surface of colonies grown on solid culture media and observed through a binocular magnifying glass.

The most common crystal morphology was dumbbell shape. It was observed for CD1, CD3, CD8, CD9, CD10, Md1, SW1, SW2, SW3. For CD2, CD4, CD7 strains, we observed crystals forming contiguous spheres. Crystals of strains CD5 and CD6 were of irregular form. The crystal length of isolated marine strains was between $30 \mu \mathrm{m}$ for CD7 and $100 \mu \mathrm{m}$ for Md1 (Fig. 4). Crystal morphology of all isolated marine bacteria did not correspond with that of spherical crystals $(30 \mu \mathrm{m})$ formed on the surface of Sporosarcina pasteurii DSM 33 for the same incubation time.

Some of the crystals present on the surface of bacterial colonies were collected and analysed by $\mu$-Raman spectroscopy. Raman spectra of crystals from three strains, CD8, CD9 and Sporosarcina pasteurii DSM 33, are shown as examples in Figure 5.

All Raman spectra exhibited a vibration band around $1085 \mathrm{~cm}^{-1}$ corresponding to the carbonate symmetric vibration mode of $\mathrm{CaCO}_{3}$ (aragonite or calcite). In the case of Sporosarcina pasteurii, aragonite was identified via Raman vibration peaks at 155,206 and a doublet at $707 \mathrm{~cm}^{-1}$ (Fig. 5b). For all other crystals obtained from marine bacterial strains, either calcite or an undefined $\mathrm{CaCO}_{3}$ was identified. Calcite is the most stable form of $\mathrm{CaCO}_{3}$ and exhibits vibration bands at 1085 and $155 \mathrm{~cm}^{-1}$ as for aragonite, but with two other typical vibration bands at 280 and $714 \mathrm{~cm}^{-1}$. Spectrum of Figure 5a obtained from CD9 bacterial strain corresponded to calcite although some slight peak shifts were observed probably due to the intense fluorescence background observed. This fluorescence background due to organic matter (biofilm, bacterial cells or remaining culture medium) was sometimes so intense that only the most intense vibration band of carbonate at $1081 \mathrm{~cm}^{-1}$ was visible (Fig. 5c). As it was not possible to identify the allotropic form of limescale, it was named as undefined type- $\mathrm{CaCO}_{3}$.

All the results for the fourteen biocalcifying bacteria isolated and grown in several solid and liquid culture media $\left(\mathrm{MB}+\mathrm{CaCl}_{2}, \quad \mathrm{MB}+\mathrm{CaCl}_{2}+\right.$ urea, $\mathrm{M} 1+\mathrm{CaCl}_{2}, \quad \mathrm{M} 1+$ $\mathrm{CaCl}_{2}+$ urea) are listed in Table 2 .

Characterization of these precipitates showed that calcite was the main $\mathrm{CaCO}_{3}$ form produced by the strains under the different culture conditions. In the liquid and solid $\mathrm{MB}+\mathrm{CaCl}_{2}$ with and without urea, all the isolated marine strains produced calcite. Moreover, in solid medium $\mathrm{MB}+\mathrm{CaCl}_{2}$ with and without urea, the shapes of crystals for $\mathrm{CD} 1, \mathrm{CD} 2, \mathrm{CD} 4, \mathrm{CD} 5$ and $\mathrm{CD} 7$ were different depending on the presence or absence of urea. In the $\mathrm{M} 1+\mathrm{CaCl}_{2}$ medium with and without urea, only CD9, CD10, Md1, SW1, SW2 and SW3 produced calcite in solid and liquid conditions. The other strains did not produce $\mathrm{CaCO}_{3}$ in solid condition except $\mathrm{CD} 8$ that showed an undefined type $\mathrm{CaCO}_{3}$ when urea was added. This can be explained by the absence in the medium of a compound necessary for biocalcification. Nevertheless, in liquid condition with and without urea, some bacteria produced $\mathrm{CaCO}_{3}$ but the spectrum obtained by Raman spectroscopy did not precisely allow to identify the $\mathrm{CaCO}_{3}$ compound obtained.

It is reported that the composition of the medium, culture methods and bacterial isolates can control the type of crystals produced $[26,27]$. This could explain why 


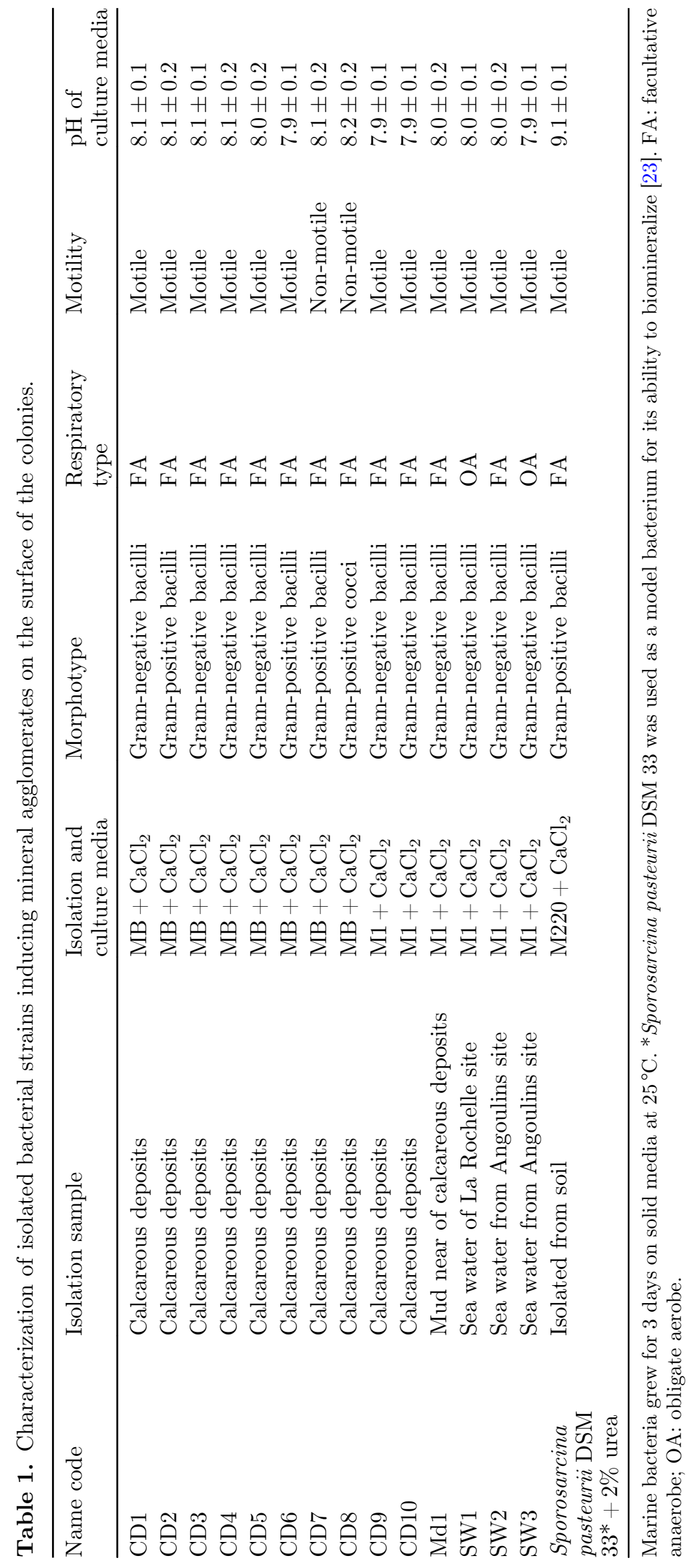



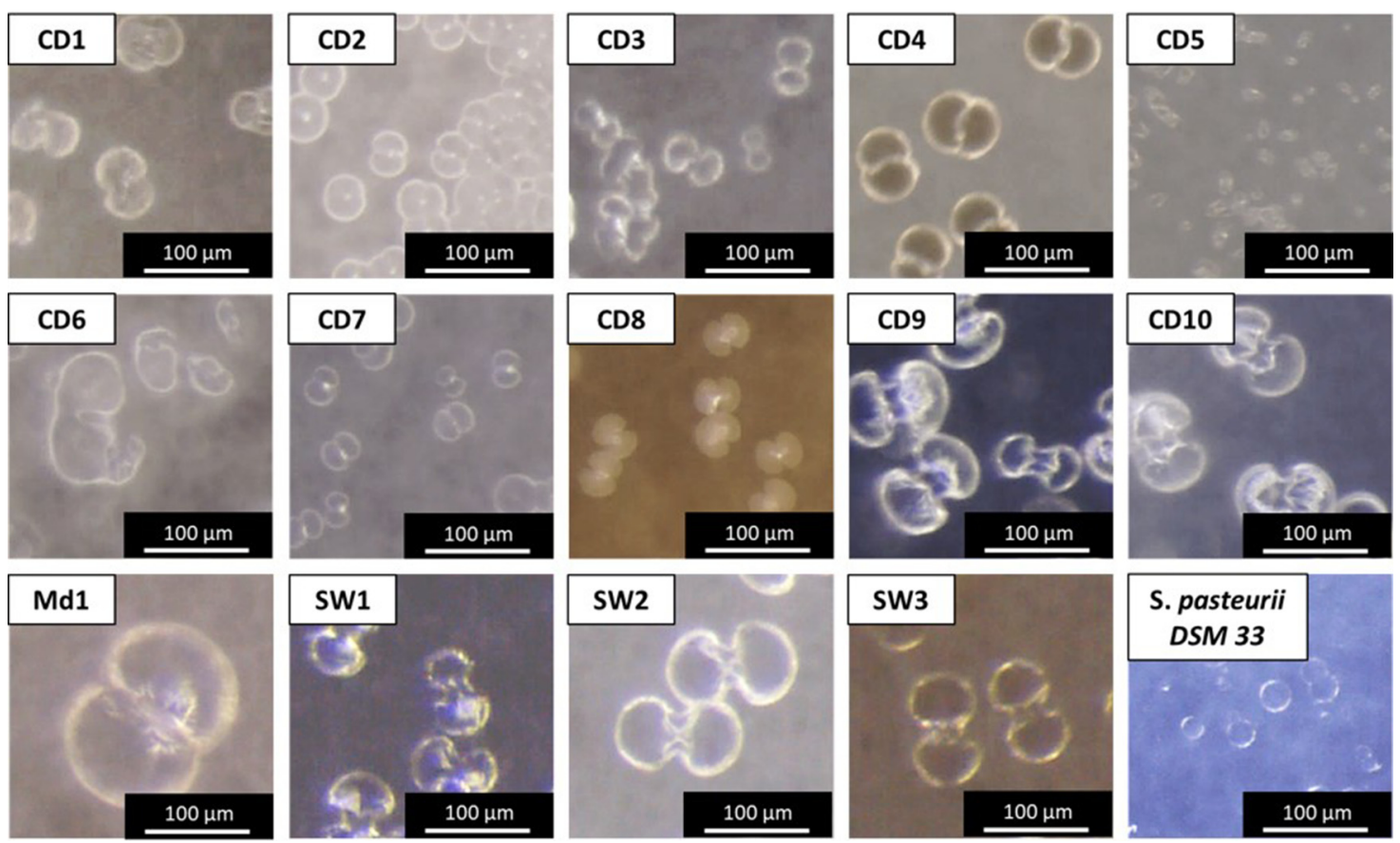

Fig. 4. Morphology of crystals observed at the surface of the colonies of marine bacterial strains inducing biomineralization. Marine bacteria grew on solid isolation media for 3 days at $28^{\circ} \mathrm{C}$. The average crystal length depends on the strain. CD7: $30 \mu m$; CD2 and CD8: $50 \mu \mathrm{m}$; CD3, SW1 and SW3: $60 \mu \mathrm{m}$; CD1: $70 \mu \mathrm{m}$; CD4, CD9, CD10, SW2: $90 \mu \mathrm{m}$; Md1:100 $\mu \mathrm{m}$; CD5 and CD6: heterogeneous. Sporosarcina pasteurii DSM 33: $30 \mu \mathrm{m}$.

Sporosarcina pasteurii DSM33 induced the formation of aragonite in the medium $\mathrm{M} 220+2 \%$ urea whereas this strain induced calcite formation in the medium $\mathrm{MB}+$ $\mathrm{CaCl}_{2}+$ urea. In different cultures of marine bacteria, the size of crystals was different (data not shown), as well as their morphology and composition, showing the differences of formed crystals mainly in accordance with microenvironment composition and isolates.

Interestingly, the nature of the compound obtained was similar in solid and liquid cultures for most isolated marine bacteria. Moreover, the fact that the marine bacterial strains induced $\mathrm{CaCO}_{3}$ precipitation both in presence and absence of urea suggests that several metabolic pathways could be involved in biocalcification, including the urease pathway in presence of urea [12] and anhydrase carbonic pathway in absence of urea [28]. Therefore, we explored whether the bacteria expressed the enzymes involved in these two metabolisms.

\subsection{Metabolic pathways involved in biomineralization}

Enzymatic colorimetric assay was used to determine presence or absence of urease and carbonic anhydrase activities, enzymatic pathways identified to play a key role in the biomineralization process (Tab. 3).

Using indole urea medium, 6 isolated marine strains were shown to have urease activity: CD6, CD9, CD10, SW1, SW2 and SW3. It is reported that urease pathway in biocalcification is sufficient to induce $\mathrm{CaCO}_{3}$ formation [10]. So, the 6 strains have the enzymatic capacity to use the urea of the culture medium as inducer of the biocalcification which is consistent with the $\mathrm{CaCO}_{3}$ production observed in presence of urea (except for CD6 in solid $\mathrm{M} 1+\mathrm{CaCl}_{2}+$ urea, Tab. 2). However, these urease-positive strains and the urease-negative strains produce $\mathrm{CaCO}_{3}$ in absence of urea in the culture medium (Tab. 2) suggesting that another metabolism was involved in biocalcification.

Using p-NPA as a colour indicator during its hydrolysis, we have determined that all isolated marine strains could exhibit carbonic anhydrase activity. This later has been found to have a great potential for production of carbonates [20,21]. Carbonic anhydrase is a major enzyme that plays an important role in carbon concentrating mechanism and sequestration of $\mathrm{CO}_{2}$ into calcium carbonate [29]. It is reported that an extracellular Bacillus carbonic anhydrase produced calcite [28]. This suggests that the carbonic anhydrase pathway alone can induce biocalcification and this may explain the formation of $\mathrm{CaCO}_{3}$ in urease-negative strains and urease-positive strains without urea in the medium. Surprisingly, for DC1 to DC8 strains, the production of $\mathrm{CaCO}_{3}$ only worked in $\mathrm{MB}+\mathrm{CaCl}_{2}$ and not in $\mathrm{M} 1+\mathrm{CaCl}_{2}$ (in presence or absence of urea). This result could be explained not only by the metabolism of the bacteria but also by the difference of the composition of the culture media. Compound(s) of the M1 medium could interfere with biocalcification.

The presence of carbonic anhydrase activity in the fourteen marine bacteria needs to be confirmed because the carbonic anhydrase assay was conducted without negative control, i.e. without known bacteria issue from the literature that does not exhibit carbonic anhydrase activity. Indeed, carbonic anhydrase enzyme is widespread 

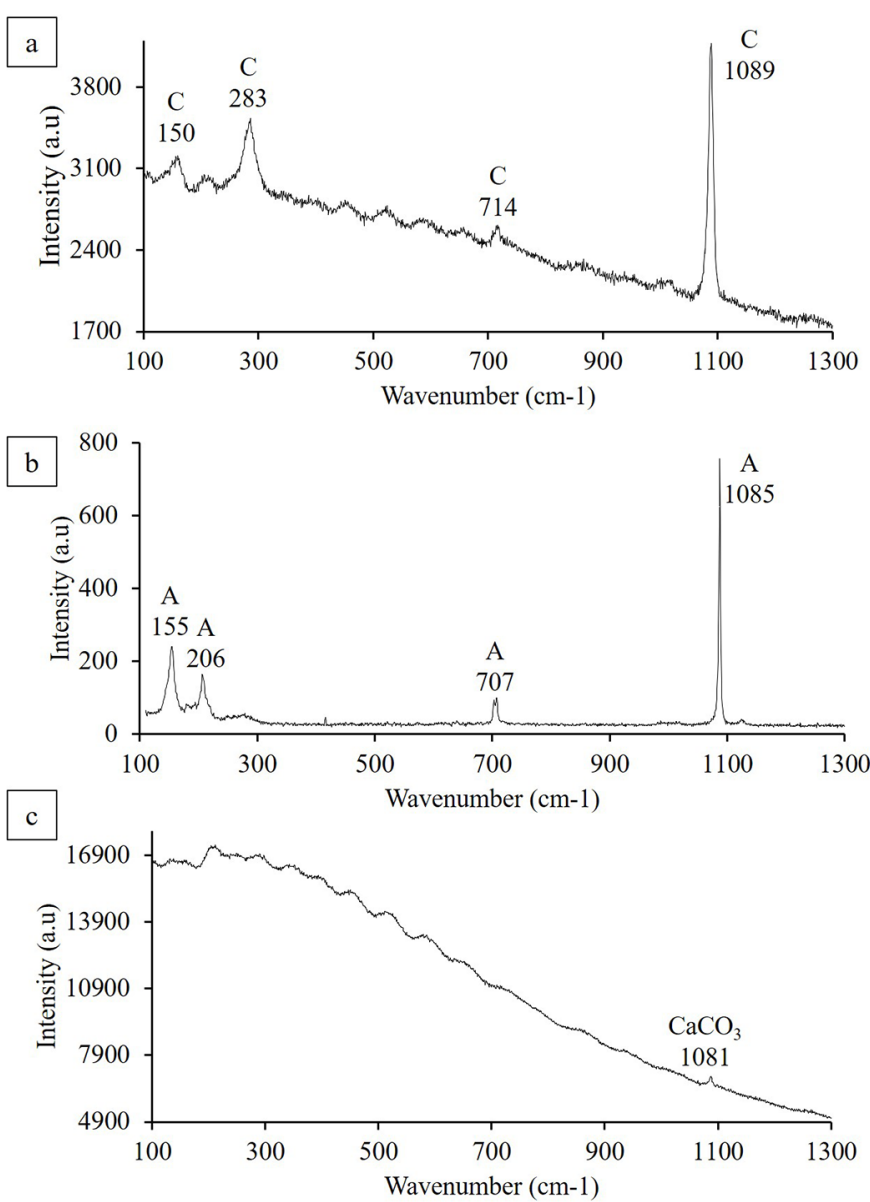

Fig. 5. Raman spectra of crystals from three bacterial strains: (a) CD9 grown on solid MB medium; (b) Sporosarcina pasteurii DSM33 grown on M220 media; (c) CD8 grown on $\mathrm{M} 1+\mathrm{CaCl}_{2}+$ urea. A: aragonite; C: calcite.

in prokaryotes [30]. Therefore, it will be necessary in an upcoming study to use another method in order to validate carbonic anhydrase activity of marine bacterial strains.

Both enzymatic pathways, urease and carbonic anhydrase, have often been studied separately as inducing biomineralization $[10,15,23,31,32]$ but it is possible that a coupling of these 2 ways would allow better biocalcification in some bacteria $[18,19,33]$. The urease pathway would provide an alkalinisation around the cells by hydrolysis of urea and the carbonic anhydrase pathway would provide an additional source of $\mathrm{HCO}_{3}{ }^{-}$.

Based on our results, 6 strains could couple the action of both enzymes: CD6, CD9, CD10, SW1, SW2 and SW3. The synergy of these 2 pathways would allow better efficiency of the precipitation of calcium carbonate.

\subsection{Assessment of biomineralization of Sporosarcina pasteurii DSM 33 by formation of sand-limestone agglomerate in the bio-solid column system}

In order to evaluate the ability of the biocalcifying seawater bacteria to agglomerate a sandy matrix with $\mathrm{CaCO}_{3}$, we have developed a bio-solid column system as presented in Figure 2. In order to validate our experimental setup, the urease positive bacterium Sporosarcina pasteurii DSM33 was used as reference strain for biomineralization [23] with the experimental conditions described in Section 2.10. After 3 weeks of treatment in the column system, solid sandy agglomerate was produced (Fig. 6). $\mu$-Raman analyses performed in zones between sand grains revealed the presence of calcite (Fig. 7). This $\mathrm{CaCO}_{3}$, produced by bacteria activity, acted as cement between sand grains. The microorganisms acted as nucleation sites for $\mathrm{CaCO}_{3}$ precipitation and the $\mathrm{CaCO}_{3}$ crystals, as they grew, finally created a bond between the grains of sand. This phenomenon has already been observed in particular when bacteria have previously been brought into contact with sand particles [34].

In this experiment, it was calcite (Fig. 7) that precipitated rather than aragonite, in contrast with what was observed during the biocalcification tests in liquid media M220 $+2 \%$ urea by Sporosarcina pasteurii DSM33 (Fig. 5b). Composition of the culture medium is one of the factors that can influence the mineral type produced by biomineralization [27], which could explain why two allotropic forms of $\mathrm{CaCO}_{3}$ could be obtained with the same bacterial strain in two different media. However, several studies demonstrated that Sporosarcina pasteurii produced calcite in similar conditions (sand, cementation medium, mould) with different experimental duration [35-38].

The most compact part of this concretion corresponded to the bottom of the column. Bernardi et al. [35] also reported that more cementation occurred on the inlet side of the cementation medium and gradually decreased throughout the brick length after the biocementation of sand by Sporosarcina pasteurii. The biased cementation at the bottom of the brick was likely due to a higher bacterial concentration at the bottom of the brick since the bacteria were regularly fed with cementation medium from the bottom to the top. We also cannot exclude a problem of sand heterogeneity throughout the column length, which would explain an irregular diffusion of the cementation medium. A piece of $50.2 \mathrm{~mm}$ long and $43.2 \mathrm{~mm}$ in diameter was then cut by a circular saw and characterized by axial compressive test, accessible water porosity, and thermogravimetric analysis.

The initial intergranular porosity, said to be accessible to water, corresponds to the initial void volume, expressed as a function of the total volume of the sample, which can potentially be filled by $\mathrm{CaCO}_{3}$ during the experiment. This porosity decreases from $40 \%$ to $20 \%$, which means that half of the inter-granular voids have been filled by $\mathrm{CaCO}_{3}$ compounds, that corresponds to about $13 \%$ of the total mass of the column. The most interesting results was the mechanical compressive strength of this block that reached 4.2 MPa, a resistance similar to that of a hollow concrete block B40 type (compressive strength required of $4 \mathrm{MPa}$ ) after only 3 weeks of experiment. These results were slightly better than those obtained by Bernardi et al. [35]. Indeed, they obtained bio-bricks with an optimum compressive strength of $2.2 \mathrm{MPa}$ and a calcite content of $3.4 \%$ after 27 days. Other biomineralization studies showed maximum mechanical compressive strengths for bio-bricks of $0.9 \mathrm{MPa}$ [23], 0.9 to $1.1 \mathrm{MPa}$ [37], 2.7 MPa [38] but no 


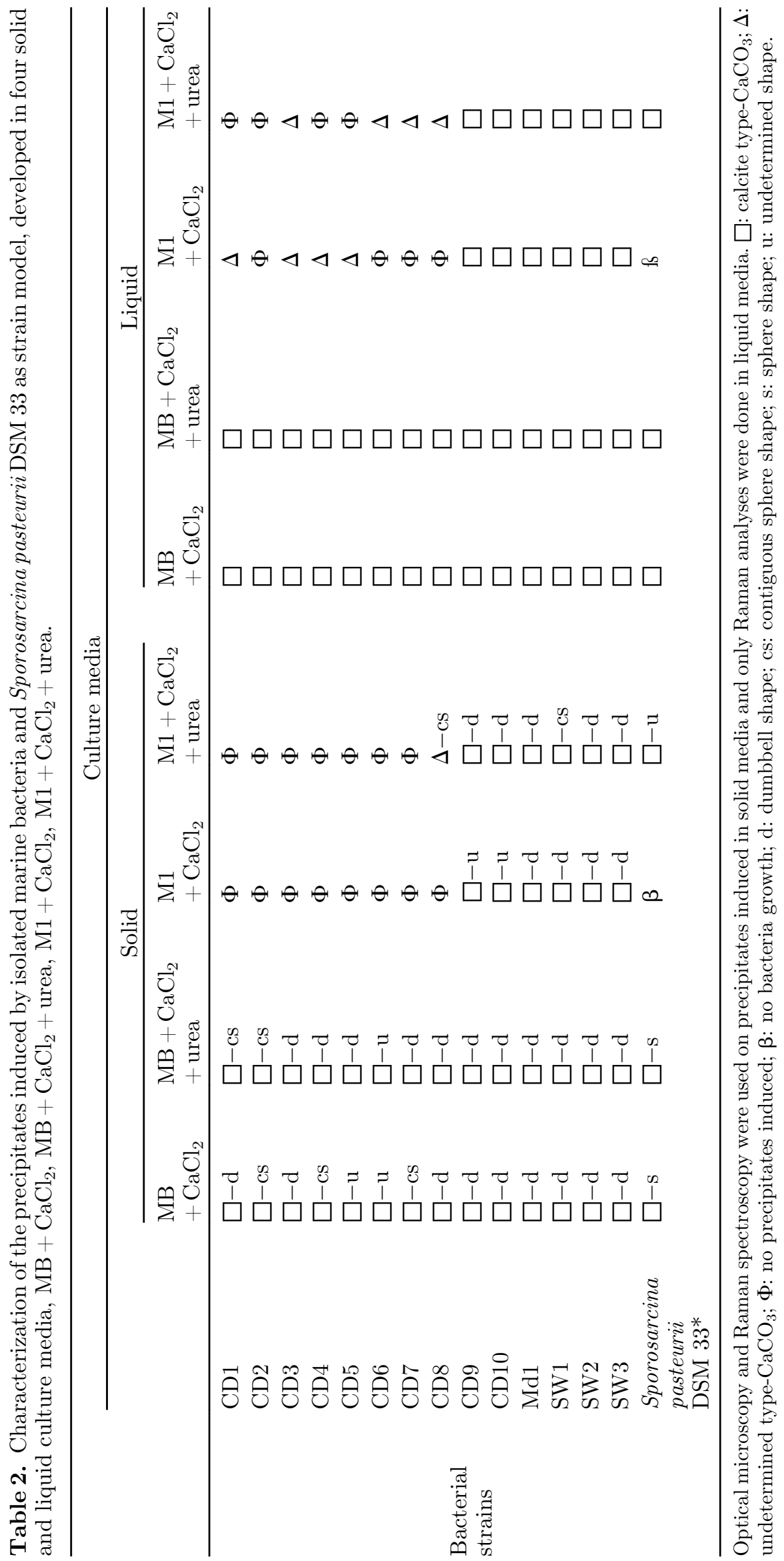


Table 3. Urease and carbonic anhydrase assay on isolates marine strains.

\begin{tabular}{lll}
\hline Name code & Urease & Carbonic anhydrase \\
\hline CD1 & - & + \\
CD2 & - & + \\
CD3 & - & + \\
CD4 & - & + \\
CD5 & - & + \\
CD6 & + & + \\
CD7 & - & + \\
CD8 & - & + \\
CD9 & + & + \\
CD10 & + & + \\
Md1 & - & + \\
SW1 & + & + \\
SW2 & + & + \\
SW3 & + & + \\
\hline
\end{tabular}
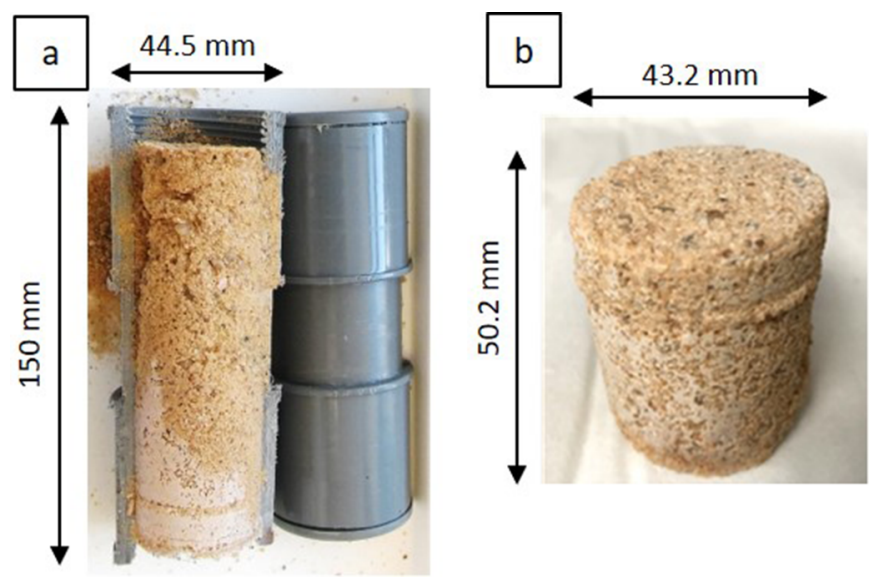

Fig. 6. Solid sand limestone aggregates obtained after 3 weeks treatment in its entirety (a). The first $5 \mathrm{~cm}$ of the column were used for analyses (b).

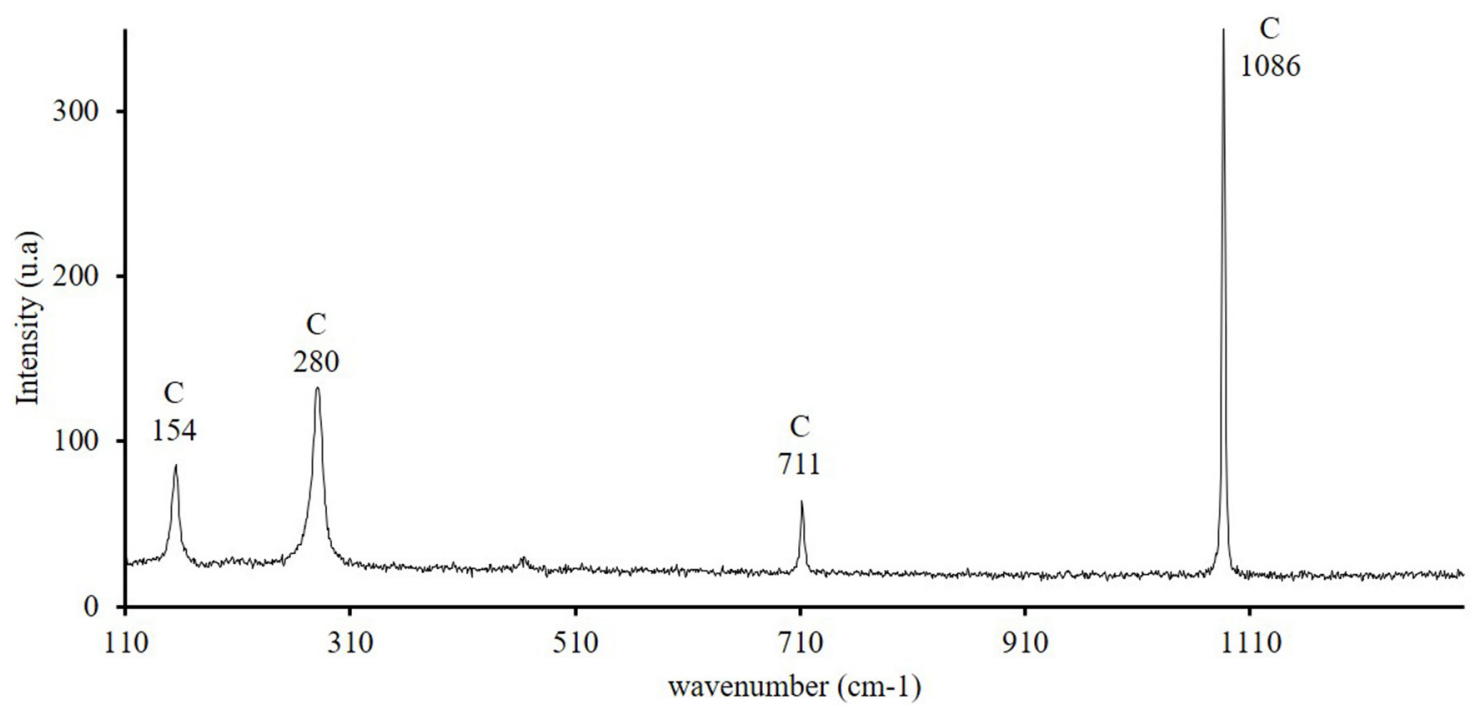

Fig. 7. Raman spectrum of the sand-limestone aggregates formed after 3 weeks treatment in the bio-solid column with Sporosarcina pasteurii DSM33. C: calcite.

values of calcite contents were given by the authors. The variation in compressive strength for the experiments reported here could be due to different liquid flow patterns, surface area of the sand and sand colonization by bacteria [37].

This test of biomineralization with Sporosarcina pasteurii DSM33 by formation of sand-limestone aggregate in the bio-solid column system could be adapted to evaluate the ability of our isolated marine strains to form $\mathrm{CaCO}_{3}$ aggregate.

\section{Conclusion}

For the first time, biocalcifying bacterial strains were isolated from calcareous deposits formed on a cathodically protected steel mesh in marine environment. They were shown to have metabolisms responsible for alkalinisation of cell environment. It resulted in $\mathrm{CaCO}_{3}$ precipitation on the cell surface under different conditions. Calcite precipitation was observed in presence and absence of urea, which suggests the involvement of several biocalcification pathways. Among the fourteen isolated strains, six had the enzymatic capacity to use the urea of the culture medium as inducer of the biocalcification whereas all of them would be carbonic anhydrase-positive. The synergy of these 2 metabolic pathways for CD6, CD9, CD10, SW1, SW2 and SW3 strains would improve the precipitation of calcium carbonate.

In parallel, we validated a column biomineralization set-up with a biocalcification model, Sporosarcina pasteurii DSM33. A solid bio-brick with a compressive 
strength similar to a hollow concrete block was obtained. This experiment can be now adapted to our biocalcifying marine bacteria to investigate their ability to agglomerate a sandy matrix in marine cementation medium.

\section{Conflict of interest}

The authors declare that they have no conflicts of interest in relation to this article.

Acknowledgments. Authors want to thank the "Communauté d'agglomération de La Rochelle" (CDA) for the financial support (PhD grant) of Julia Vincent. We also acknowledge the La Rochelle sailing harbour that enabled us to set up an in situ platform for natural seawater experiments.

\section{References}

1. GéoLittoral, «Indicateur national de l'érosion côtière », 29 janvier 2016, http://www.geolittoral.developpement-dura ble.gouv.fr/indicateur-national-de-l-erosion-cotiere-r473. html

2. A. Zanibellato, Synthèse et études physico-chimiques d'un agglomérat calcomagnésien formé sur acier en milieu marin : un éco-matériau pour la protection du littoral, $\mathrm{PhD}$ thesis, Université de La Rochelle, 2016

3. W.A. Hamilton, Microbially influenced corrosion as a model system for the study of metal microbe interactions: a unifying electron transfer hypothesis, Biofouling 19, 65-76 (2003)

4. F. Shiraishi, et al., Cyanobacterial exopolymer properties differentiate microbial carbonate fabrics, Sci. Rep. 7(1), 11805 (2017)

5. T. Danjo, S. Kawasaki, Formation mechanisms of beachrocks in Okinawa and Ishikawa, Japan, with a focus on cements, Mater. Trans. 55(3), 493-500 (2014)

6. E. Gérard, et al., Key role of Alphaproteobacteria and Cyanobacteria in the formation of stromatolites of Lake Dziani Dzaha (Mayotte, Western Indian Ocean), Front. Microbiol. 9 (2018)

7. M.J. Castro-Alonso, L.E. Montañez-Hernandez, M.A. Sanchez-Muñoz, M.R. Macias Franco, R. Narayanasamy, N. Balagurusamy, Microbially Induced Calcium Carbonate Precipitation (MICP) and its potential in bioconcrete: microbiological and molecular concepts, Front. Mater. 6, 126 (2019)

8. S. Castanier, G. Le Métayer-Levrel, J.-P. Perthuisot, Cacarbonates precipitation and limestone genesis - the microbiogeologist point of view, Sediment. Geol. 126, 9-23 (1999)

9. C. Dupraz, R.P. Reid, O. Braissant, A.W. Decho, R.S. Norman, P.T. Visscher, Processes of carbonate precipitation in modern microbial mats, Earth Sci. Rev. 96(3), 141-162 (2009)

10. B. Krajewska, Urease-aided calcium carbonate mineralization for engineering applications: a review, J. Adv. Res. 13, 59-67 (2018)

11. Y. Al-Salloum, S. Hadi, H. Abbas, T. Almusallam, M. A. Moslem, Bio-induction and bioremediation of cementitious composites using microbial mineral precipitation - A review, Constr. Build. Mater. 154, 857-876 (2017)
12. M. Hosseini, F. Babaha, M.T.Sh. Al-Rubaye, Ureaseproducing halophilic bacteria isolated from Bahr Al-Milh Salt Lake, Karbala, Iraq, J. Pure Appl. Microbiol. 11(2), 711-716 (2017)

13. J. Dick, et al., Bio-deposition of a calcium carbonate layer on degraded limestone by Bacillus species, Biodegradation 17 (4), 357-367 (2006)

14. N.K. Dhami, Biomineralization of calcium carbonate polymorphs by the bacterial strains isolated from calcareous sites, J. Microbiol. Biotechnol. 23(5), 707-714 (2013)

15. X. Zhao, M. Wang, H. Wang, D. Tang, J. Huang, Y. Sun, Study on the remediation of Cd pollution by the biomineralization of urease-producing bacteria, Int. J. Environ. Res. Public. Health 16(2) (2019)

16. S. Krause, et al., Marine ammonification and carbonic anhydrase activity induce rapid calcium carbonate precipitation, Geochim. Cosmochim. Acta 243, 116-132 (2018)

17. S.A. Abo-El-Enein, A.H. Ali, F.N. Talkhan, H.A. AbdelGawwad, Utilization of microbial induced calcite precipitation for sand consolidation and mortar crack remediation, HBRC J. 8(3), 185-192 (2012)

18. N.K. Dhami, M.S. Reddy, A. Mukherjee, Synergistic role of bacterial urease and carbonic anhydrase in carbonate mineralization, Appl. Biochem. Biotechnol. 172(5), 2552$2561(2014)$

19. V. Achal, X. Pan, Characterization of urease and carbonic anhydrase producing bacteria and their role in calcite precipitation, Curr. Microbiol. 62(3), 894-902 (2011)

20. B.H. Jo, S.-K. Im, H.J. Cha, Halotolerant carbonic anhydrase with unusual N-terminal extension from marine Hydrogenovibrio marinus as novel biocatalyst for carbon sequestration under high-salt environments, J. CO2 Util. 26, 415424 (2018)

21. A.D. Ghelani, C.B. Bhagat, P.R. Dudhagara, S.V. Gondalia, R.K. Patel, Biomimetic sequestration of $\mathrm{CO}_{2}$ using carbonic anhydrase from calcite encrust forming marine actinomycetes, Sci. Int. 3(2), 48-57 (2015)

22. G.A. Silva-Castro, I. Uad, A. Gonzalez-Martinez, A. Rivadeneyra, J. Gonzalez-Lopez, M.A. Rivadeneyra, Bioprecipitation of calcium carbonate crystals by bacteria isolated from saline environments grown in culture media amended with seawater and real brine, BioMed Res. Int. 2015 (2015)

23. J. Henze, D.G. Randall, Microbial induced calcium carbonate precipitation at elevated $\mathrm{pH}$ values $(>11)$ using Sporosarcina pasteurii, J. Environ. Chem. Eng. 6(4), 5008-5013 (2018)

24. H. Agogué, D. Lamy, P.R. Neal, M.L. Sogin, G.J. Herndl, Water mass-specificity of bacterial communities in the North Atlantic revealed by massively parallel sequencing, Mol. Ecol. 20(2), 258-274 (2011)

25. L. Chen, et al., Variation in microbial community structure in surface seawater from Pearl River Delta: discerning the influencing factors, Sci. Total Environ. 660, 136-144 (2019)

26. C. Jimenez-Lopez, C. Rodriguez-Navarro, G. Piñar, F.J. Carrillo-Rosúa, M. Rodriguez-Gallego, M.T. GonzalezMuñoz, Consolidation of degraded ornamental porous limestone stone by calcium carbonate precipitation induced by the microbiota inhabiting the stone, Chemosphere $\mathbf{6 8}$ (10), 1929-1936 (2007)

27. A. López-Moreno, J.D. Sepúlveda-Sánchez, E.M. Mercedes Alonso Guzmán, S. Le Borgne, Calcium carbonate precipitation by heterotrophic bacteria isolated from biofilms 
formed on deteriorated ignimbrite stones: influence of calcium on EPS production and biofilm formation by these isolates, Biofouling 30(5), 547-560 (2014)

28. S. Sundaram, I.S. Thakur, Induction of calcite precipitation through heightened production of extracellular carbonic anhydrase by $\mathrm{CO}_{2}$ sequestering bacteria, Bioresour. Technol. 253, 368-371 (2018)

29. A. Kaplan, L. Reinhold, $\mathrm{CO}_{2}$ concentrating mechanisms in photosynthetic microorganisms, Annu. Rev. Plant Physiol. Plant Mol. Biol. 50(1), 539-570 (1999)

30. K.S. Smith, J.G. Ferry, Prokaryotic carbonic anhydrases, FEMS Microbiol. Rev. 24(4), 335-366 (2000)

31. G.M. Bond, J. Stringer, D.K. Brandvold, F.A. Simsek, M.-G. Medina, G. Egeland, Development of integrated system for biomimetic $\mathrm{CO}_{2}$ sequestration using the enzyme carbonic anhydrase, Energy Fuels 15(2), 309-316 (2001)

32. N. Favre, M.L. Christ, A.C. Pierre, Biocatalytic capture of $\mathrm{CO}_{2}$ with carbonic anhydrase and its transformation to solid carbonate, J. Mol. Catal. B Enzym. 60(3-4), 163-170 (2009)
33. J.N. Priya, M.K. Nan, Effect of carbonic anhydrase and urease on bacterial Calcium carbonate precipitation, Int. J. Pharma Bio Sci. 8(3) (2017)

34. F. Hammes, W. Verstraete, Key roles of $\mathrm{pH}$ and calcium metabolism in microbial carbonate precipitation, Rev. Environ. Sci. Biotechnol. 1(1), 3-7 (2002)

35. D. Bernardi, J.T. DeJong, B.M. Montoya, B.C. Martinez, Bio-bricks: biologically cemented sandstone bricks, Constr. Build. Mater. 55, 462-469 (2014)

36. H.-J. Chen, Y.-H. Huang, C.-C. Chen, J. P. Maity, C.-Y. Chen, Microbial Induced Calcium Carbonate Precipitation (MICP) using pig urine as an alternative to industrial urea, Waste Biomass Valoriz. 10(10), 2887-2895 (2019)

37. S.G. Choi, J. Chu, R.C. Brown, K. Wang, Z. Wen, Sustainable biocement production via microbially induced calcium carbonate precipitation: use of limestone and acetic acid derived from pyrolysis of lignocellulosic biomass, ACS Sustain. Chem. Eng. 5(6), 5183-5190 (2017)

38. S.E. Lambert, D.G. Randall, Manufacturing bio-bricks using microbial induced calcium carbonate precipitation and human urine, Water Res. 160, 158-166 (2019)

Cite this article as: Julia Vincent, René Sabot, Isabelle Lanneluc, Philippe Refait, Philippe Turcry, Pierre-Yves Mahieux, Marc Jeannin, Sophie Sablé, Biomineralization of calcium carbonate by marine bacterial strains isolated from calcareous deposits, Matériaux \& Techniques 108, 302 (2020) 